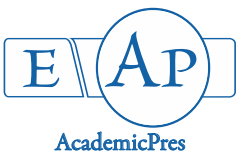

Emmanuel-Akerele HA et al. (2021)

Notulae Scientia Biologicae

Volume 13, Issue 2, Article number 10858

DOI: $10.15835 / \mathrm{nsb} 13210858$

Short Review

\title{
Hog plums: Its importance, potentials and future prospects
}

\section{Hilda A. EMMANUEL-AKERELE ${ }^{1 *}$, William O. TANIMOWO ${ }^{1}$, Ogochukwu F. OLISE ${ }^{1,2}$}

\author{
${ }^{1}$ Anchor University, Department of Biological Sciences, Lagos, Nigeria; akatahhilda@gmail.com ("${ }^{*}$ corresponding author); \\ wtanimowo@aul.edu.ng; folise@aul.edu.ng \\ ${ }^{2}$ University of Benin, Department of Plant Biology and Biotechnology, Environmental Biotechnology and Sustainability Research \\ Group, Nigeria; ofo2double@gmail.com
}

\begin{abstract}
Hog plums, scientifically known as Spondias mombin are medicinal plants that are rich in nutrients and antioxidants, and are of great importance in the food/agricultural industries and the health sector. In the food industries, it is an important fruit crop that can be eaten raw, juiced and processed for making jam, ice cream and jellies, and also provides farmers an alternative feeding material for lactating ruminants to help in galactogenesis and lactopoiesis. In the health sector, hog plums fruit, leaves and stem extract possess antimicrobial, cytotoxic, anti-tyrosinase, diuretic and febrifuge activities for the treatment of certain disease conditions, and it can be effectively preserved by wax coating of the fruits. Methanolic extract of Spondias contain methyl gallate, a substance that has the potential to facilitate apoptotic cell death in human glioblastoma, lung, and breast cancer Hog plums are also rich in vitamins, it strengthens the immune system, protects against heart disease, and stimulates the production of collagen which keeps the body healthy. It is a plant that has obvious and promising health benefits, and as such more research into its properties is advisable. Preservation of hog plum can be achieved by wax coating, retardation of ripening and senescence, and application of growth regulators.
\end{abstract}

Keywords: antimicrobial; antioxidants; anti-tyrosinase; cytotoxic; Spondias mombin

\section{Introduction}

Medicinal plants are rich in various phytochemical compounds that possess anti-oxidative properties (Sameh et al., 2018), and are considered as healthy sources for the prevention of various oxidative-stress related diseases, inflammation and microbial diseases (Ayoka et al., 2008). Hog plum as it is commonly called, is scientifically known as Spondias mombin is a deciduous tree with large panicles of small white flowers and yellow plum-like fruits, grown mainly during rainy season, between June and August (Adepoju and Oyewole, 2008). Fruits of the plant are ovoid, yellow, fleshy, drupe and are borne within a cluster of 10-15 fruits; unripe fruits taste sour, while ripe ones have sweet-sour taste. It belongs to the family Anarcadiaceae (same family as Cashews, Mangoes and Pistachios) (Patathananone et al., 2019), natively found in Central America and the Carribean and in Southern Nigeria (Ayoka et al., 2008). Hog plum, a medicinal plant and fruit crop has several common names; it is called 'iyeye'/'akika'/'ebo' in Yoruba, 'ngulungwu' in Ibo, 'isada'/'tsardamaster' in Hausa,

Received: 29 Nov 2020. Received in revised form: 10 Mar 2021. Accepted: 12 Apr 2021. Published online: 23 Apr 2021.

From Volume 13, Issue 1, 2021, Notulae Scientia Biologicae journal uses article numbers in place of the traditional method of continuous pagination through the volume. The journal will continue to appear quarterly, as before, with four annual numbers. 
'chabbuh' in Fulani, 'oheeghe' in Edo, 'aginiran' in Ijaw, 'kakka' in Tiv, 'nuskakara' in Efik, 'bala' in Costa Rica, 'jobito' in Panama, 'jobo blanco' in Colombia, 'jobo corronchoso' in Venezuela, 'hoeboe' in Surinam, 'acaiba'/'caja'/'pau da tapera' in Brazil, 'ubo' in Peru and 'hobo' in Mexico (Gbile and Soladoye, 2002).

\section{Nutritional Composition}

Hog plums are composed of carbohydrates (13.80 g), fats (0.62 g), protein (1.06 g), ash (0.75 g), moisture $(83.6 \mathrm{~g})$, energy $(65.4 \mathrm{~g})$, dietary fibre $(1.87 \mathrm{~g})$, sodium $(5.5 \mathrm{mg})$, iron $(0.33 \mathrm{mg})$, potassium $(287 \mathrm{mg})$, phosphorus $(32.7 \mathrm{mg})$, manganese $(0.03 \mathrm{mg})$, magnesium $(15 \mathrm{mg})$, calcium $(11 \mathrm{mg})$, copper $(0.12 \mathrm{mg})$, lutein $(634 \mu \mathrm{g}), \beta$-carotene $(314 \mu \mathrm{g}), \alpha$-carotene $(340 \mu \mathrm{g})$, zeinoxanthin $(550 \mu \mathrm{g}), \beta$-criptoxanthin $(1700 \mu \mathrm{g})$ (Adepoju and Oyewole, 2008), while the seed kernel contains carbohydrate (40.56\%), ash (8.09\%), crude fibre (31.86\%), moisture content $(8.48 \%)$, crude protein $(7.73 \%)$, crude fat $(3.28 \%)$, calcium $(1317 \mathrm{mg} / \mathrm{kg})$, iron $(839.08$ $\mathrm{mg} / \mathrm{kg})$, magnesium $(494.71 \mathrm{mg} / \mathrm{kg})$, manganese $(17.93 \mathrm{mg} / \mathrm{kg})$, zinc $(15.27 \mathrm{mg} / \mathrm{kg})$, and copper $(7.68 \mathrm{mg} / \mathrm{kg})$ (Makinde et al., 2016). Phytochemical analyses showed the presence of tannins $(0.06 \%)$ and phytate $(0.0022 \%)$ (Makinde et al., 2016). The free radical scavenging activity against the 2,2-diphenyl-1-picrylhydrazyl (DPPH) radical was at the level of $15.09 \%$, while total antioxidant capacity and total phenolic content were $856.7 \pm 5.84 \mathrm{mg} \mathrm{AAE} / 100 \mathrm{~g}$ and $573.32 \pm 11.5 \mathrm{mg} \mathrm{GAE} / 100 \mathrm{~g}$ respectively (Patathananone et al., 2019). These antioxidants help to reduce oxidation stress caused by free radicals in the body that could damage the body's major organs (Nwidu et al., 2017). The seed kernel of Spondias mombin has anti-anaemic and anti-diabetic properties as a result of iron and zinc content (Sameh et al., 2018). It is a potential chemo-protective agent against the activities of the toxic reactive oxygen species (ROS) (Fred and Abo, 2009).

Hog plums are also rich in vitamin $\mathrm{C}$, a natural antioxidant, which strengthens the immune system, protects against heart disease, and stimulates the production of collagen which keep the body healthy (Nwidu et al., 2017). A $100 \mathrm{~g}$ portion of hog plums contains $46 \mathrm{mg}$ of vitamin C, and a $100 \mathrm{~g}$ serving of hog plums has $2.8 \mathrm{mg}$ of iron, this provides 15 - 35\% of the recommended intake of iron per day (Patathananone et al., 2019). Iron is essential for the production of haemoglobin and myoglobin, which carry oxygen through the body. Saronee et al. (2019) reported on the antioxidant content and effectiveness of hog plums in rat hearts. The study showed that hog plums were high in antioxidants when compared to the heart medication, ramipril and they also discovered that Spondias mombin reduced overall cholesterol levels and its effect on heart health was comparable to that of ramipril (Saronee et al., 2019). Hog plums are fat free, cholesterol-free, rich in vitamin K (which aids blood clotting, strengthen bones and prevents bone fractures) and thiamine (which prevents muscle contraction and promotes conduction of nerve signals) (Nwidu et al., 2017). Spondias also possess sedative, anxiolytic, anti-helminthic, antimicrobial and anti-inflammatory properties (Abo et al., 1999).

\section{Uses}

\section{Medical and antimicrobial use}

In traditional medicine, hog plum leaves are used to make tea for stomach ache, biliousness, urethritis, cystitis, inflammation, treatment of gonorrhoea, diabetes and psychiatric disorders (Kasote et al., 2015), expulsion of placenta in goats (Kasote et al., 2015), an oxytocic agent; (Aiyeloja and Bello, 2006), and in wound treatment (Kasote et al., 2015). The fruit has been used as a diuretic (to effectively reduce blood pressure by removing salts and unwanted fluid from the body through urine) and febrifuge (used as a substitute for fever medication due to the presence of flavonoids, anthraquinones, sesquiterpenes and quinolone). The bark is an astringent and used as an emetic (Sameh et al., 2018), for diarrhea, dysentery, hemorrhoids, gonorrhoea, and leukorrhea (Aiyeloja and Bello, 2006). The leaf extract has antimicrobial properties, can be used in making antiseptic soap, and is active against bacterial, fungal and parasitic infections (Kasote et al., 2015). 


\section{Organ repair}

Ubah et al. (2018), reported that the administration of methanolic leaf extract of Spondias mombin was potent in ameliorating the effects of zidovudine induced oxidative stress on the liver histology of rats.

A study was carried out on the hypothalamus, pituitary, and adrenal glands (HPA axis) of Zidovudine stress induced Wistar rats and showed that the administration of methanolic leaf extract of Spondias mombin proved a restorative effect on the HPA axis when exposed to oxidative stress (Ubah et al., 2018). Another researcher carried out a study on the hepatoprotective and anti-oxidant effects of Spondias mombin leaf and stem extracts upon carbon tetrachloride induced hepatotoxicity and oxidative stress (Nwidu et al., 2017). The study showed that extract of Spondias mombin may serve as a promising herb for the treatment of hepatic damage (Nwidu et al., 2017).

Assessment of methanolic extract of Spondias mombin leaves on blood glucose and glycosylated haemoglobin using male rats showed that Spondias mombin possess anti-diabetic and hypoglycaemic properties (Saronee et al., 2019). Phytochemicals present in hog plums reduce blood glucose through stimulation of insulin from residual beta cells; (Fred and Abo, 2009) enhancement of glucose transport to body tissues; (Saronee et al., 2019) and inhibition of gastrointestinal absorption of glucose (Sameh et al., 2018).

\section{Food and agriculture}

Spondias mombin is an important fruit crop that can be eaten raw, juiced and processed for making jam, ice cream and jellies (Adepoju and Oyewole, 2008). Hog plum provides farmers with an alternative feeding material for lactating ruminants to help in galactogenesis and lactopoiesis (Sameh et al., 2018), due to increase in the cost of grains used in the production of concentrate diets (Udeh and Oguike, 2008).

In food industries, the enzyme tyrosinase catalyses the browning reactions in food products due to loss in nutritional quality during storage (Patathananone et al., 2019). Therefore, ripe hog plums fruits which possess anti-tyrosinase activity and low cytotoxicity with normal cells could be formulated as food additives for the inhibition of enzymatic browning of food products (Kim and Uyama, 2005).

\section{Skin and cancer treatment}

Aging which is a normal situation of life is influenced by intrinsic (decreasing hormone, increasing age, etc.) and extrinsic (sunlight, smoking, etc.) factors (Popoola et al., 2015). Also, reactive oxygen species (ROS) production increases in cells associated with the UV radiation from sunlight (Garg et al., 2017). ROS are a group of free radicals that enhance the activity of elastase, collagenase, and hyaluronidase enzymes. These enzymes can degrade the structural components of extracellular matrix (elastin, collagen, hyaluronic acid) in cells (Popoola et al., 2015), changing the physiological and progressive structure of the skin (Garg et al., 2017). Hyperpigmentation of the skin may be induced by the catalytic activity of tyrosinase enzyme (Kim and Uyama et al., 2005). therefore, bioactive components (phenolics and flavonoids) in ripe hog plum can inhibit tyrosinase activity in the skin and prevent aging (Popoola et al., 2015).

The methanolic extract of Spondias was found to contain methyl gallate (Sameh et al., 2018), a substance that has the potential to facilitate apoptotic cell death in human glioblastoma, lung, and breast cancer (George et al., 2017). Ripe hog plum fruits exhibit anti-tyrosinase, anti-elastase, and anticancer activity due to the presence of bioactive compounds (gallic acid and gallic glycoside) which are used in cosmetic, food preservation and as a cytotoxic agent (Sun et al., 2016). Gallic acid and methyl gallate isolated from the ethyl acetate extraction of hog plum bark showed a cytotoxic effect on human glioblastoma cell line (U87) (George et al., 2017). Gallic acid present in hog plums can also enhance $G_{0} / G_{1}$ phase arrest and apoptosis in human leukaemia HL-60 cells (Patathananone et al., 2019), by inhibiting cyclin D and E and activating the mitochondriadependent pathway (Kim, 2007). 


\section{Preparation of fruit and leaf extract}

Fruits are washed with water including $70 \% \mathrm{v} / \mathrm{v}$ ethanol thrice and air dried. Peel and pericarp are collected, homogenized using a homogenization machine and frozen dry. $200 \mathrm{~g}$ of dried powder are placed into the chambers, and methanol added in a ratio of $1: 4 \mathrm{w} / \mathrm{v}$ (Sameh et al., 2018). The extracted chambers are shaken at $180 \mathrm{rpm}$ for $72 \mathrm{~h}$. The supernatant is collected and filtered with Whatman No. 1 filter paper. The precipitate is be extracted using methanol, hexane, ethyl acetate, isopropanol or ethanol respectively (Aiyeloja and Bello, 2006).

Fresh leaves of Spondias mombin are dried at room temperature for a minimum of 14 days and extracted using the percolation method as described by Aiyeloja et al. (2006). The Spondias mombin leaves are grounded into powder, $8.8 \mathrm{~kg}$ of the powder is macerated with $98 \%$ methanol for three days, then filtered and concentrated using rotary evaporator at $40{ }^{\circ} \mathrm{C}$ (Kasote et al., 2015). The obtained extract is kept in air tight containers and can be stored at room temperature before use.

\section{Collection/Harvesting of fruits}

Fruit harvested from 9 - 11 weeks after fruit set are found to be of optimum maturity, with high concentrations of spondiol and moderate levels of climacteric respiration (Li et al., 2014). Hog plum fruit has a shelf life of 10 days (Bhakat et al., 1997). Immature fruit show a rapid deterioration in their bioactive and biochemical constituents after harvest, and have a shorter shelf-life of 2 - 3 days. Over-mature fruit (i.e., fruit harvested $\geq 11$ weeks after fruit set), have a shelf-life of $8-10$ days show a rapid decline in bioactive and biochemical constituents and shrinking of the peel and pulp from the endocarp, which renders the fruit unfit for fresh consumption or processing (Adepoju and Oyewole, 2008).

\section{Preservation}

Wax coating, an effective method for preserving fruits, helps in controlling transpiration and respiration rate (Sameh et al., 2018). Retardation of ripening and senescence, and application of growth regulators can also minimise fruit weight loss and prolong storage of hog plum fruits (Bhakat et al., 1997). A study showed that hog plums preserved with wax emulsion (\%) coating could be stored well up to 2 weeks with minimum spoilage (33.3\%) and physiological loss in weight at room temperature (Li et al., 2014).

\section{Conclusions}

Spondias mombin also known as Hog plum is one of the medicinal plants that are rich in various phytochemical compounds that possess antioxidants and phytochemicals, which include, tannins and phytate. It also has nutritional compositions which include carbohydrates, fats, protein, ash, moisture, energy, dietary fibre, sodium, iron, potassium, phosphorus, manganese, magnesium, calcium, copper, zinc, lutein, $\beta$-carotene, $\alpha$-carotene, zeinoxanthin, and $\beta$-criptoxanthin.

In addition, it is used in traditional medicine for treating illnesses. For instance, hog plum leaves are used to make tea for treating stomach ache, biliousness, urethritis, cystitis, inflammation, gonorrhoea, diabetes and psychiatric disorders. Hog plums are also rich in vitamin C, a natural antioxidant, which strengthens the immune system, protects against heart disease, and stimulates the production of collagen which keeps the body healthy. It is a plant that has obvious and promising health benefits, and as such more research into its properties is advisable. 


\section{Authors' Contributions}

Conceptualization: HAE-A; Data Curation: HAE-A, OFO; Formal analysis: HAE-A, WOT; Writingoriginal draft: HAE-A; Writing-review and editing: HAE-A, WOT and OFO.

All authors read and approved the final manuscript.

\section{Acknowledgements}

This research received no specific grant from any funding agency in the public, commercial, or not-forprofit sectors.

\section{Conflict of Interests}

The authors declare that there are no conflicts of interest related to this article.

\section{References}

Abo KA, Ogunleye VO, Ashidi JS (1999). Antimicrobial potential of Spondias mombin, Croton zambesicus and Zygotritonia crocea. Phytotheraphy Research 13(6):494-497. https://doi.org/10.1002/(SICI)1099-1573

Adepoju OT, Oyewole OE (2008). Nutrient composition and acceptability study of fortified jams from Spondias Mombin (Hog Plum, Iyeye in Yoruba) fruit pulp. Nigerian Journal of Nutritional Science 29(2):180-189. http://www.sciepub.com/reference/104872

Aiyeloja AA, Bello OA (2006). Ethnobotanical potentials of plants in Nigeria. A case study of Enugu State. Educational Research and Review Science International Journal 1(1):16-22. https://www.scirp.org/

Ayoka AO, Akomolafe RO, Akinsomisoye OS, Ukponmwan OE (2008). Medicinal and economic value of Spondias mombin. African Journal of Biomedical Research 11(2):129-136. https://doi.org/10.4314/ajbr.v11i2.50714

Bhakat SK, Hore JK, Sen SK (1997). Extension of storage life of hog plum (Spondias dulcis). Indian Journal of Plant Physiology 2(2):177-178.

Esua OJ, Makinde OO, Arueya GL, Chin NL (2016). Antioxidant potential, phytochemical and nutrient compositions of Nigerian hog plum (Spondias mombin) seed kernel as a new food source. International Food Research Journal 23(5):179-185.

Fred-Jaiyesimi A, Abo K (2009). Anti-diabetic activity of Spondias mombin extract in NIDDM rats. Pharmaceutical Biology 47(3):215-218. https://doi.org/10.1080/13880200802462493

Garg C, Khurana P, Garg M (2017). Molecular mechanisms of skin photoaging and plant inhibitors. International Journal of Green Pharmacy 11(2):217-232. http://dx.doi.org/10.22377/ijgp.v11i02.1031

George VC, Dellaire G, Rupasinghe HPV (2017). Plant flavonoids in cancer chemoprevention: role in genome stability. Journal of Nutrient Biochemistry 45:1-14. https://doi.org/10.1016/j.jnutbio.2016.11.007

Gbile ZO, Soladoye MO (2002). Vernacular names of Nigerian plants (Yoruba). (2nd ed). Forestry Research Institute of Nigeria (FRIN) Press, Ibadan Nigeria pp 101. https://www.scirp.org/

Kasote DM, Katyare SS, Hegde MV, Bae H (2015). Significance of antioxidant potential of plants and its relevance to therapeutic applications. International Journal of Biological Sciences 11(8):982-991. https://doi.org/10.7150/ijbs.12096

Kim YJ, Uyama H (2005). Tyrosinase inhibitors from natural and synthetic source: structure, inhibition mechanism and prospective for the future. Cellular Molecular Life Sciences 62:1707-1723. https://doi.org/10.1007/s00018$005-5054-y$

Kim YJ (2007). Antimelanogenic and antioxidant properties of gallic acid. Biological and Pharmacological Bulletin 30:1052-1055. https://doi.org/10.1248/bpb.30.1052 
Li NA, Li S, Zhang YJ, Xu XR, Chen YM, Li HB (2014). Resources and biological activities of natural polyphenols. Nutrients 6(1):6020-6047. https://doi.org/10.3390/nu6126020

Nwidu LL, Elmorsy E, Yibala OI, Carter WG (2017). Hepato-protective and antioxidant effects of Spondias mombin leaf and stem extracts upon carbon tetrachloride induced hepatotoxicity and oxidative stress. Journal of Basic and Clinical Pharmacy 8(2):5-18. https://doi.org/10.1016/j.jtumed.2018.03.006

Patathananone S, Daduang J, Koraneekij A, Li C (2019). Tyrosinase Inhibitory effect, antioxidant and anticancer activities of bioactive compounds in ripe hog plum (Spondias pinnata) fruit extracts. Oriental Journal of Chemistry 35(3):1-12. http://dx.doi.org/10.13005/ojc/350302

Popoola OK, Marnewick JL, Rautenbanch F, Ameer F, Iwuoha EI, Hussein AA (2015). Inhibition of oxidative stress and skin aging-related enzymes by prenylated chalcones and other flavonoids from Helichrysum teretifolium. Molecules 20:7143-7155. https://doi.org/10.3390/molecules20047143

Sameh S, Al-Sayed E, Labib RM, Singab AN (2018). Genus Spondias: A phytochemical and pharmacological review. Evidenced Based Complementary and Alternative Medicine (4):1-13. https://doi.org/10.1155/2018/5382904

Saronee F, Bekinbo MT, Ojeka SO, Dapper DV (2019). Comparative Assessment of methanolic extracts of hog plum (Spondias mombin linn.) Leaves and turmeric (Curcuma longa L.) rhizomes on blood glucose and glycosylated haemoglobin in male Wistar rats. Journal of Applied Science and Environmental Management 23(9):16311636. https://doi.org/10.4314/jasem.v23i9.4

Sun G, Zhang S, Xie Y, Zhang Z, Zhao W (2016). Gallic acid as a selective anticancer agent that induces apoptosis in SMMC-7721 human hepatocellular carcinoma cells. Oncology Letters 11(1):150-158. https://doi.org/10.3892/ol.2015.3845

Ubah CO, Asuquo OR, Oko GE, Ewaa OI, Eluwa MA (2018). Evaluating the effects of methanolic leaf extract of neem plant and hog plum on the liver histology of zidovudine induced-oxidative stress Wistar rats. Journal of Complementary and Alternative Medical Research 6(4):1-6. https://doi.org/10.9734/JOCAMR/2018/46306

Ubah CO, Asuquo OR, Oko GE, Eluwa MA (2018). Comparative effects of methanolic leaf extracts of Azadirachta indica and Spondias mombin on the hypothalamicpituitary-adrenal axis of zidovudine stress induced Wistar rats. Annual Research and Review in Biology 29(5):1-15. https://doi.org/10.9734/ARRB/2018/45293

Udeh NE, Oguike MA (2008). Influence of Spondias mombin l (hog plum) on colostrum, milk composition and growth in west African dwarf sheep. Animal Production Research Advances 4:3-4. https://doi.org/10.4314/apra.v4i34.49779

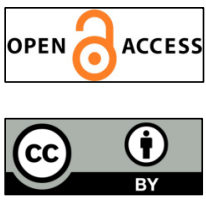

The journal offers free, immediate, and unrestricted access to peer-reviewed research and scholarly work. Users are allowed to read, download, copy, distribute, print, search, or link to the full texts of the articles, or use them for any other lawful purpose, without asking prior permission from the publisher or the author.

License - Articles published in Notulae Scientia Biologicae are Open-Access, distributed under the terms and conditions of the Creative Commons Attribution (CC BY 4.0) License.

(c) Articles by the authors; SHST, Cluj-Napoca, Romania. The journal allows the author(s) to hold the copyright/to retain publishing rights without restriction. 